\title{
Regional-scale meltwater erosion and deposition patterns, northern Quebec, Canada
}

\author{
T. A. BRENNAND, \\ Simon Fraser Universily, Department of Geography, Burnaby, British Columbia V5A 1SG, Canada \\ J. SHAW, \\ Department of Earth and Atmospheric Sciences, University of Alberta, Edmonton, Alberta T6G 2H4, Canada \\ D. R. SHARPE \\ 2557 Hanlon Avenue, Ottawa, Ontario K2B $7 \times 2$. Canada
}

\begin{abstract}
Glaciofluvial ridges, several hundred kilometres long, are commonly referred to as interlobate moraines because they appear to have formed at the convergence of two distinct ice lobes. Flow convergence is indicated by patterns of striations, streamlined forms and eskers. The so-called interlobate moraines are also thought to have formed asynchronously as the ice margin retreated. By contrast, we argue that the Harricana moraine of northern Quebec, Canada, formed following flow convergence in a regional-scale subglacial outburst flood. Flowlines constructed from streamlined bedforms mapped on the glacial map of Canada, reinterpretation of these streamlined forms as products of meltwater erosion, and field records of erosional marks (S-forms) in bedrock and glaciofluvial deposits to the lee of bedrock highs support this model. The effects of this flow convergence on the ice-sheet topography and drainage controlled the location of the broad conduit in which the Harricana moraine was deposited. Continued flow in this conduit and melting of the conduit walls explain the local patterns of striae, the supply of debris to the conduit, and the morphological and sedimentary characteristics of the moraine itself. From these characteristics, we conclude that the moraine was formed synchronously. This conclusion, if correct, is instructive regarding the deglacial hydrological organization of a large sector of the Laurentide ice sheet.
\end{abstract}

\section{INTRODUCTION}

The term "interlobate moraine" has been applied to broad accumulations of mainly sand and gravel, arranged in almost continuous ridges and irregular mounds (Punkari, 1980). Such elevated and linear glaciofluvial sediments have been attributed to deposition in an icecontact environment during deglaciation (e.g. Veillette, 1986). They have been identified in Finland, Russia and Canada (e.g. Punkari, 1980, 1985; Dredge and Cowan, 1989).

The interlobate-moraine interpretation is based on observations and inferences not so much from the landform itself as from its relationship to surrounding landforms and its stratigraphic context. For example, striae, eskers and "glacial lineations" converge on interlobate moraines, and have been inferred to record lobate ice flow (e.g. Dyke and Prest, 1987). Further, interlobate moraines are traditionally suggested to have been formed time-transgressively as the ice margin retreated (e.g. Veillette, 1986).

Identification of interlobate moraines rests on the inference of lobate ice flow. Traditional reconstruction of ice-flow patterns depends on evidence from fields of "glacial lineations" and striae. An underlying assumption is that all "glacial lineations" (drumlins, flutings, cragand-tails, roches moutonnées, after Prest and others (1968)) were formed directly by flowing ice. This fundamental assumption is presently under debate see Shaw, 1994b) and should be tested.

Here, we discuss the geomorphology and sedimentology of an interlobate moraine, the Harricana moraine, Quebec, Canada (Fig. 1), in the context of surrounding landforms and derived event sequences. We propose an alternative interpretation of the genesis of the moraine and associated landforms and, by extension, of ice-sheet dynamics and hydrology during late-Wisconsinan deglaciation of the Labrador sector of the Laurentide ice sheet.

\section{THE HARRICANA MORAINE}

The Harricana moraine is a relatively continuous ridge of stratified sand and gravel which may extend from a chain of islands in James Bay, through a dissected portion of the 


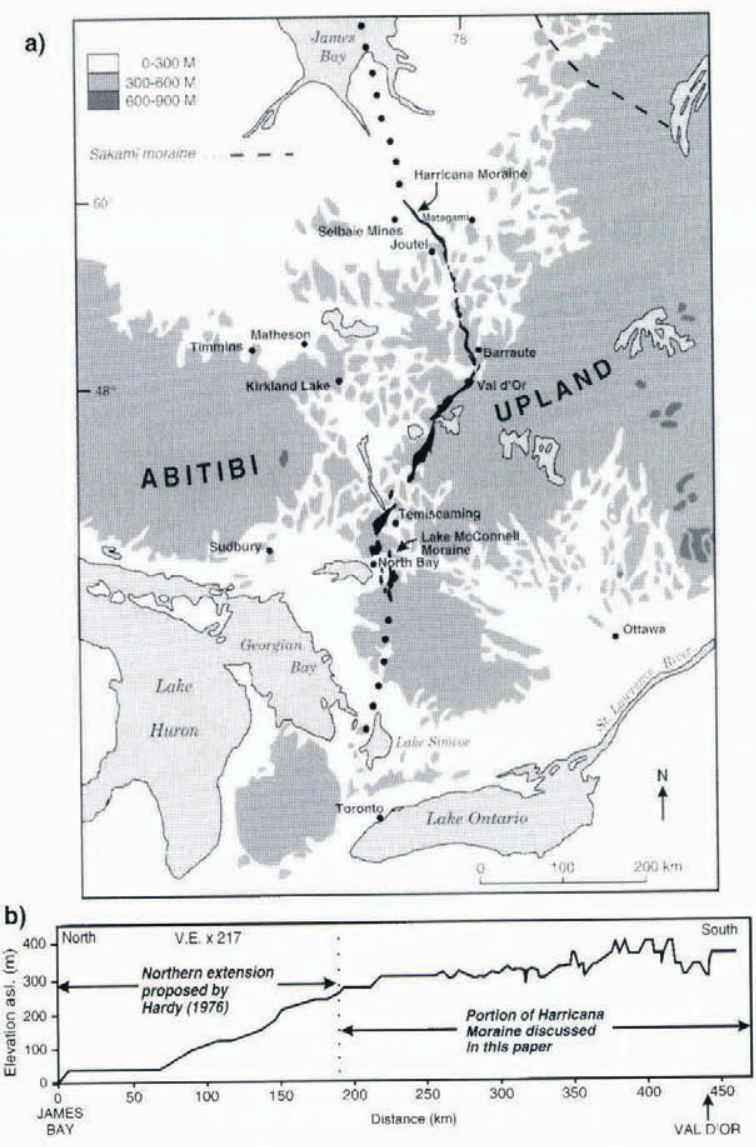

Fig. 1. (a) Location of the Harricana moraine and (b) crest-long profile from James Bay to Val d'Or (modified from Brennand and Shaw (in press)).

Abitibi uplands, as far south as Lake Simcoe $(\sim 1000 \mathrm{~km}$; Veillette, 1986) (Fig. 1). Existing interpretations, based largely on regional context, favour time-transgressive glaciofluvial formation of the moraine in an unzippering re-entrant in the ice sheet (Veillette, 1986). Veillette (1990) suggested that this unzippering may have been triggered by subglacial deformation and ice downdraw in the Great Lakes region. Here we present observations on the Harricana moraine in order to constrain (i) the depositional environment, (ii) the glaciological conditions, and (iii) the meltwater regime. Our observations are from $48-50^{\circ} \mathrm{N}$ in the Abitibi region of Quebec (Fig. 1).

\section{General depositional environment}

The moraine is a southward-widening ridge with an upslope path to the south (Fig. 1). It mainly consists of gravel and sand macroforms (Brennand and Shaw, in press). Post-depositional deformation of ridge sediments is primarily limited to faults, characteristic of removal of lateral ice support (McDonald and Shilts, 1975). Taking sedimentary architecture into account (Brennand, 1994), paleoflow direction estimates from gravel fabrics and cross-bedded and cross-laminated sand are unidirectionally southward (Fig. 2). Greatest variability is recorded in lower-flow-regime sand facies. Taken together these observations favour deposition in a continuous, subglacial conduit (Brennand and Shaw, in press) as opposed to episodic, segmental, ice-marginal deposition.
In situ clast characteristics are indicators of transportational processes, distance and vigour (Sneed and Folk, 1958). Resistant granitoid clasts are most common in 11 of the 12 most northerly pits, whereas less resistant metabasalt clasts are more frequent in six of the seven most southerly pits (Fig. 3). There is no such regional trend in bedrock geology (Fig. 3) or in the composition of surface samples of Matheson Till; McClenaghan (1990) found that the composition of surface samples of Matheson Till reflected changes in the composition of local bedrock. Different transportational vigour and differential comminution best explain this regional clast partitioning. Vigorous transport in a relatively narrow conduit to the north resulted in lower deposition rates, rapid comminution and the dominance of resistant granitoid clasts. Less vigorous transport in a wider conduit to the south resulted in higher deposition rates, less pronounced differential comminution and a lithological composition more closely reflecting the composition of the source rock or sediment (Matheson Till?).

In situ clasts in the moraine are generally sub-rounded to rounded (cf. Powers, 1953), suggesting fluvial transport (Sneed and Folk, 1958; Fig. 4). A regional trend in clast roundness emerges. North of pit Q17, clasts are predominantly well rounded, whereas south of pit Q12 most clasts are sub-rounded (Fig. 4). As with the regional trend in clast lithology, a southward decrease in clast roundness is most simply attributed to a decrease in transportational vigour and/or distance southward in a continuous conduit. It is probable that clasts were continuously transported to the conduit from lateral sources; the concept of a single point source does not apply.

These regional trends in clast characteristics further support an interpretation of the Harricana moraine as an enormous esker deposited synchronously in a subglacial conduit.

\section{Glaciological conditions}

From basic geomorphic and sedimentary observations a southward-widening conduit and southward-declining flow power are inferred. Such conduit characteristics favour a southward-thinning ice sheet. To the north, the maintenance of flow of high power in a relatively narrow conduit necessitated relatively thick ice to ensure that conduit closure rate kept pace with melt rate. To the south, reduced melting rate in a wider conduit with lower flow power balanced the reduced closure rate beneath a relatively thin ice sheet.

\section{Meltwater regime}

The moraine is composed of ridge-scale gravel macroforms which include facies of fluvially rounded boulders upwards of $1 \mathrm{~m}$ in diameter (Brennand and Shaw, in press). Such bedforms suggest a high-energy meltwater regime. In addition, many macroforms exhibit vertically stacked, gravel-sand couplets Brennand and Shaw, in press). Gravel-sand couplets are best explained by floods, likely controlled by seasonally produced supraglacial meltwater connecting with the subglacial drainage system, on seasonal or episodic time-scales (Brennand, 

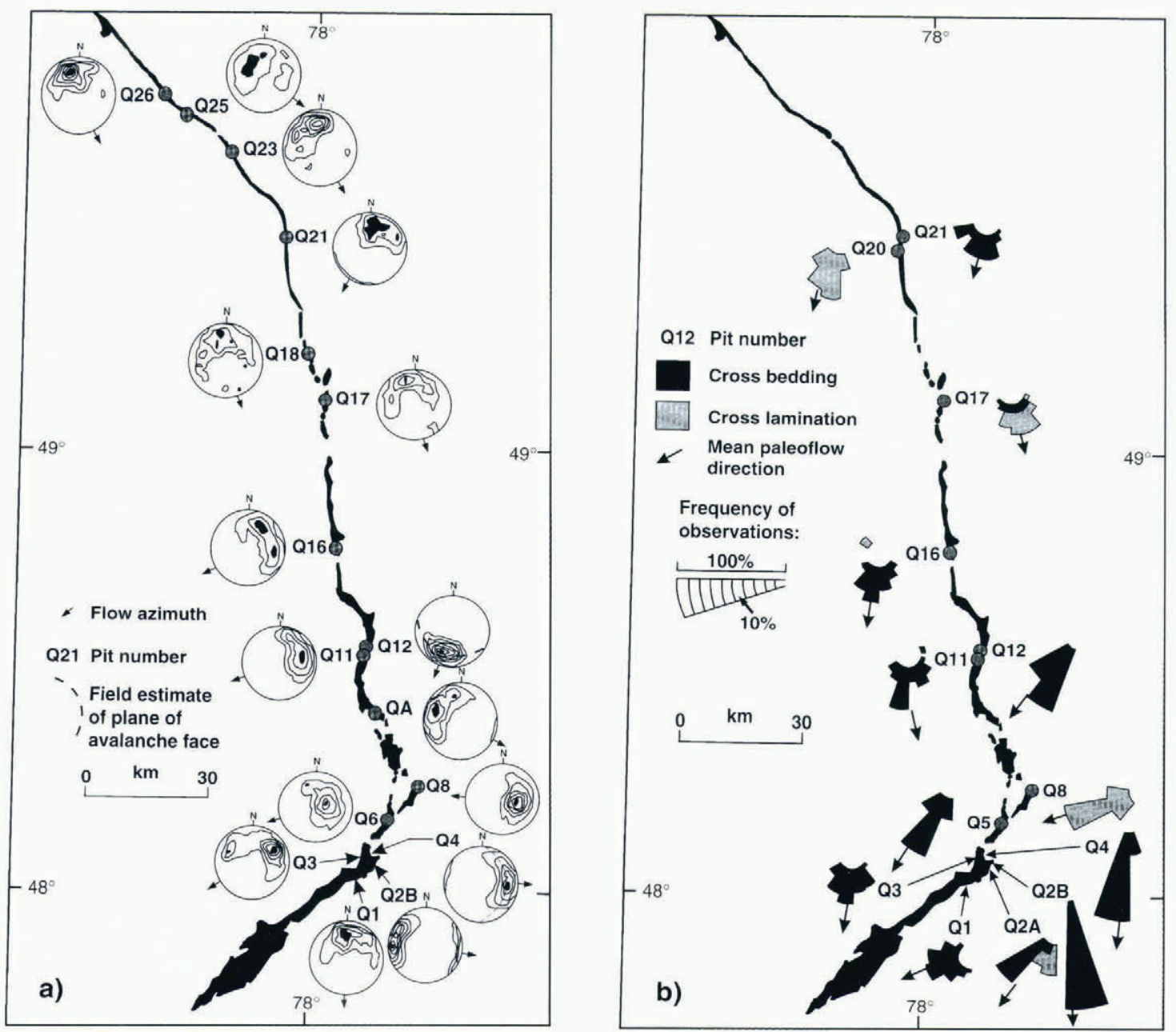

Fig. 2. Paleoflow direction estimates from (a) gravel fabrics and (b) cross-bedded and cross-laminated sand (modified from Brennand and Shaw (in press)). Fabrics are displayed as equal-area, lower-hemisphere plots.

1994).

This new interpretation of the Harricana moraine as an enormous esker deposited synchronously by powerful, pulsed meltwater flows in a continuous, subglacial conduit beneath a southward-thinning ice sheet differs markedly from the existing time-transgressive, icemarginal interpretation (cf. Veillette, 1986). If this alternative interpretation is to have any credence it must be rationalized with event sequences derived from its regional context.

\section{REGIONAL CONTEXT}

Synchronous deposition of the Harricana moraine in a continuous conduit poses difficult questions regarding the characteristics of the Laurentide ice sheet around the time the moraine formed. The circumstances by which such a long drainage path came into existence are particularly intriguing. As well, any explanation of the evolution of the Harricana moraine must accord with the evidence of "glacial lineations" mapped by Prest and others (1968) and striae mapped by Veillette (1986), that record flow events before and during the formation of the moraine. Thus, understanding the evolution of the moraine requires that various signatures of ice-sheet behaviour be placed in sequence and that transitions from one stage to the next follow logically.

Striae in this region give a remarkably consistent account of flow sequences (Veillette, 1986). There are two distinct younger sets: an earlier set indicating a regional southwesterly flow (Fig. 5a), and a later set that indicates flow convergence on the Harricana moraine (Fig. 5c). There is also a set of large-scale "glacial lineations", mainly drumlins, flutings and crag-and-tail hills, indicating regional flow to the southwest, but including broadscale divergence and convergence, prior to the formation of the Harricana moraine and associated eskers (Prest and others, 1968; Fig. 6). Landforms of the Cochrane advances and the Sakami moraine with its associated eskers and De Geer moraines were created after the Harricana complex and are superimposed on features produced by the regional southwest flow. This separation in time of land-formation stages and flow events allows a general reconstruction of ice-sheet evolution (Fig. 5) that sets the scene for more specific interpretation of landforming processes.

\section{REGIONAL-SCALE OUTBURST FLOODS}

Flowlines reconstructed from "glacial lineations" mapped by Prest and others (1968), excluding landforms clearly related to such younger events as the Cochrane surges, 


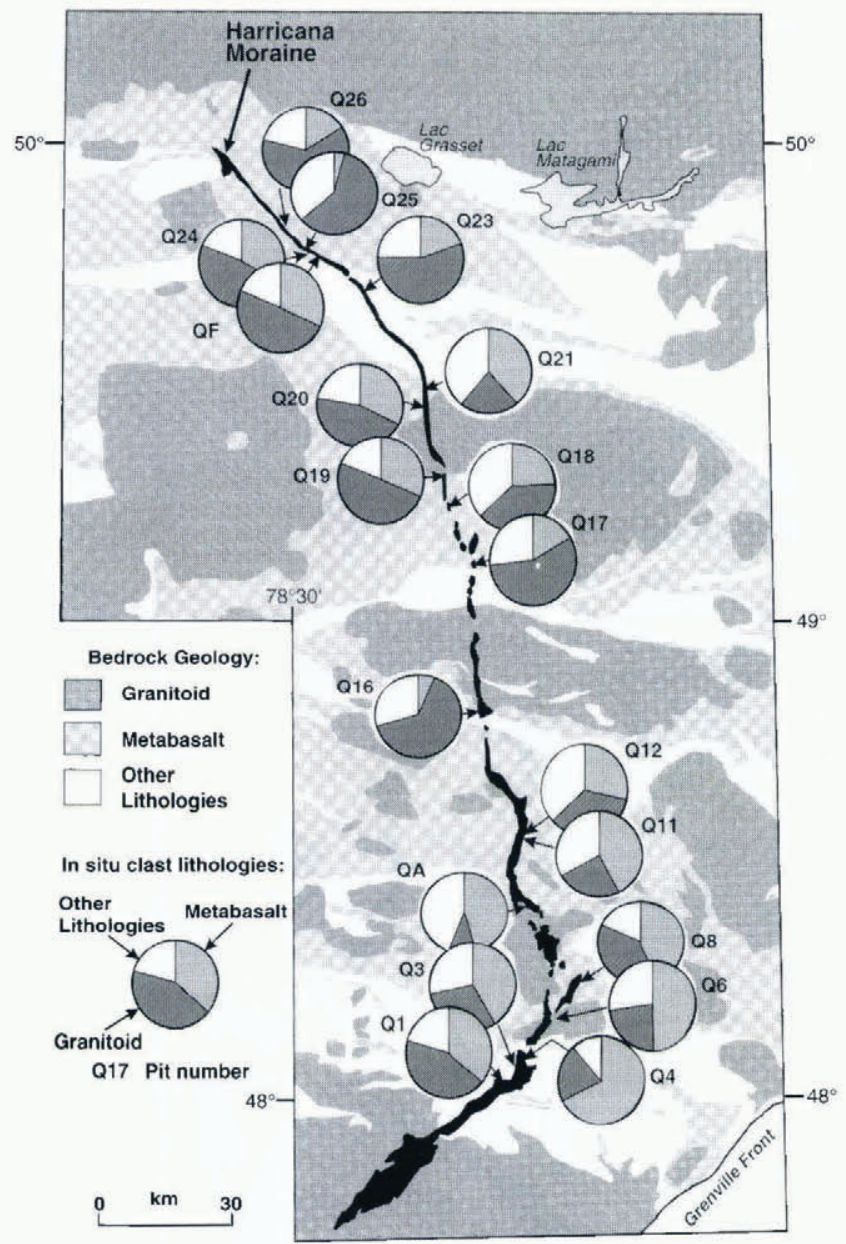

Fig. 3. In situ clast lithology recorded in pit exposures within the Harricana moraine (modified from Brennand and Shaw (in press)). Bedrock geology modified from MERQ-OGS (1983).

show a coherent regional pattern (Fig. 6). The features mapped as lineations in this area are mainly drumlins, flutings and crag-and-tail hills, although some roches moutonnées may be included. A striking feature of the flowline pattern is the convergence in the area where the Harricana moraine was subsequently formed.

How might such flow convergence and the location of

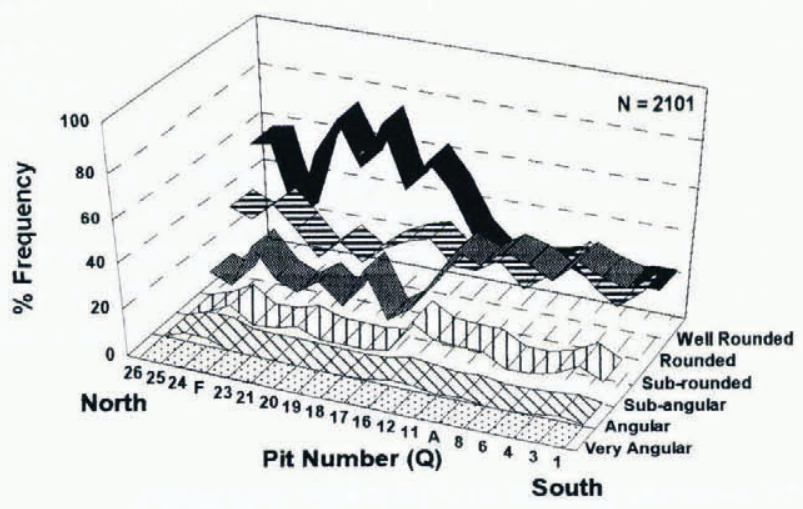

Fig. 4. Downflow trends in in situ clast roundness (cf. Powers, 1953) (modified from Brennand and Shaw (in press)).
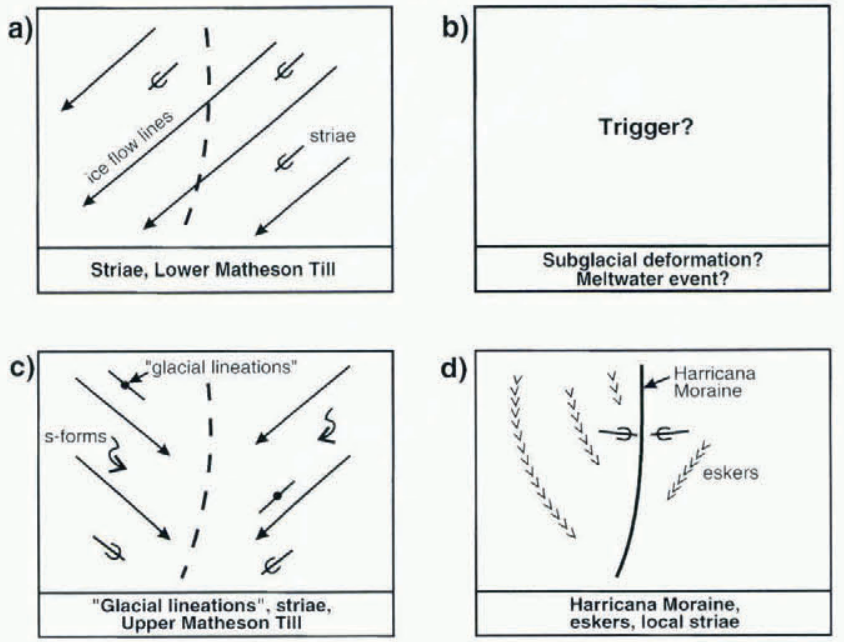

Fig. 5. Regional event sequence derived from landform and stratigraphic context ( $c$. Veillelle, 1986). See text for explanation.

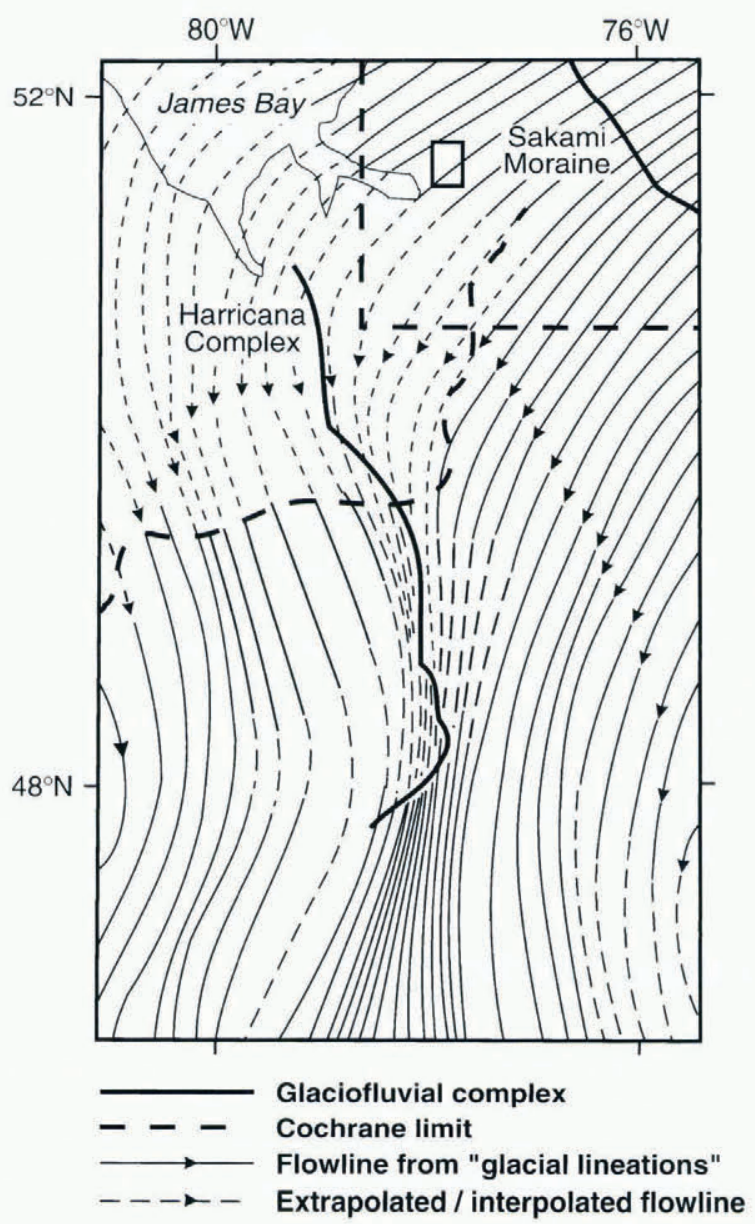

Fig. 6. The position of the Harricana moraine with respect to regional flowlines reconstructed from "glacial lineations" on the glacial map of Canada (Prest and others, 1968) (modified from Brennand and Shaw (in press)). Note that the flowlines are continuous either side of the Sakami moraine. The solid line inset shows the location of Figure 8; the dashed line insel shows part of the outline of the full satellite scene. 
the Harricana moraine be related? One hypothesis for the formation of drumlins and flutings is that they were formed by regional-scale meltwater outburst floods (see Shaw, 1994b). By proceeding on the assumption that the outburst-flood hypothesis is correct, we may determine the significance of the relationship between the flow pattern and the location of the Harricana moraine.

A zone of convergence in a water-sheet flow following regional southwesterly ice flow (Fig. 5a) would have been a zone of relatively high discharge per unit width (Fig. 7a). Higher rates of melting in this zone relative to adjacent areas would have induced convergent ice flow from the sides and from above to replace melting ice. Drawdown would have resulted and an ice-surface trough would have formed along this zone (Fig. 7b). Ice flow towards this trough produced regionally convergent striae (Figs 5c and $7 \mathrm{~b}$ ). The trough would have also funnelled supraglacial drainage, and, following the short-lived sheet-flood stage, meltwater making its way to the bed would have maintained a large subglacial conduit in which the Harricana moraine was later deposited (Fig. 7c). Low pressure in the Harricana conduit accounts for local ice indraw and meltwater flow at the bed which, in turn, explain local, late-stage striations convergent on the moraine and the convergence of eskers on the moraine (Figs 5d and 7c). This explanation, based on an assumption of meltwater floods, has the advantages of simplicity and unity. It is tested here by more detailed study of a selected area.

\section{THE PONTAX AREA}

The Pontax area lies close to the Sakami moraine and includes extensive areas of streamlined bedforms (Fig. 8). A full satellite scene of the area including the Sakami moraine shows no change in streamlined bedform alignment, pattern or form at this moraine note the full scene cannot be reproduced here with sufficient resolution to show the bedforms). Eskers and De Geer moraines are found in abundance to the northeast of the Sakami moraine but are less common to the southwest (Prest and others, 1968). Evidently the moraine, eskers and De Geer moraines are superimposed on lineations created when the ice sheet extended well beyond the position of the Sakami moraine. Flowlines indicated by the streamlined forms attest, at least in the area of the satellite scene, to the accuracy of the regional flowline pattern we mapped from Prest and others (1968) (Fig. 6).

Field observation and air-photo analysis indicate that the streamlined bedforms are in bedrock and surficial deposits and commonly have bedrock exposed at their stoss ends. Hairpin scours wrapped around the stoss ends of many streamlined forms point to their formation by meltwater erosion (Shaw, 1994a). The meltwater interpretation is further supported by widespread S-forms produced by southwesterly-flowing meltwater (Fig. 9).

A large sand-and-gravel deposit forms a ridge extending southwest from a bedrock high at the Pontax communication tower (Fig. 10). The ridge parallels

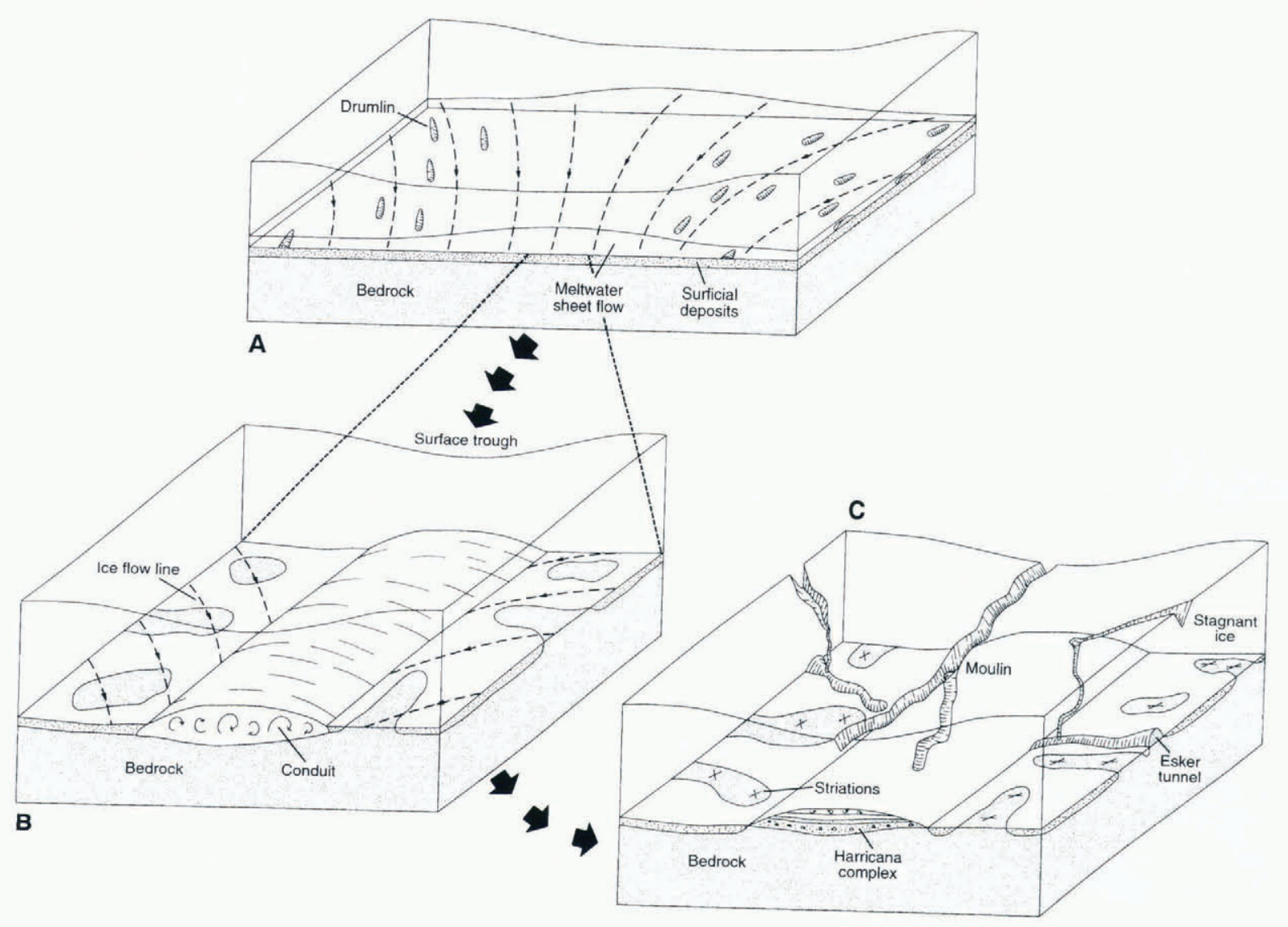

Fig. 7. Proposed sequence of events leading to the formation of the Harricana moraine (modified from Brennand and Shaw (in press)). (a) Broad-sheet flow stage; (b) early conduil stage; (c) Harricana conduil stage. (a) and (b) were probably short-lived stages (a matter of weeks), whereas (c) probably represents conditions over a long period of time, possibly several thousand years. 


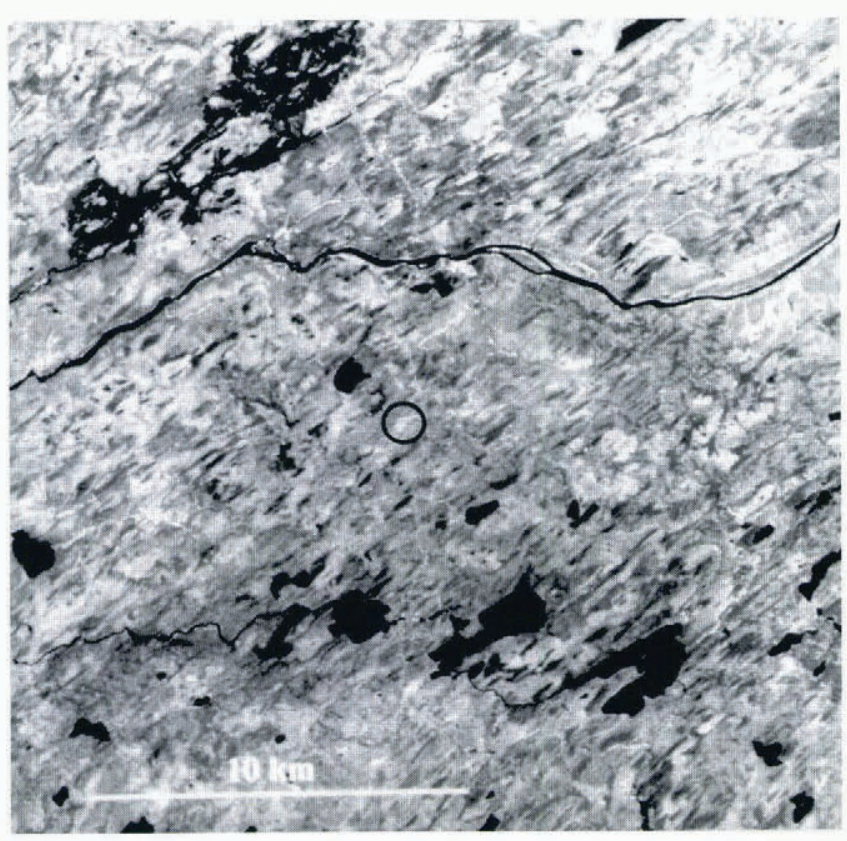

Fig. 8. Landsal thematic mapper image, band 4, showing Pontax site (301 km north on Matagami-Radisson road) located within a field of streamlined forms oriented approximately northeast-southwest. See Figure 6 for location.

others in its vicinity. Rounded boulders were deposited close to the bedrock high (Fig. 1la), and as the elevation of the ridge falls towards the southwest the boulders give way to cobbles, which in turn give way to pebbly sand and then sand (Fig. $11 \mathrm{~b}$ ). Orientation of the ridge parallel to the drumlins and sediment-fining towards the southwest suggest that the ridge is a primary form deposited to the lee of a bedrock obstacle (Fig. 10). An alternative interpretation is that the Pontax site is a littoral deposit (personal communication from A.S. Dyke, 1995). We cannot rationalize the sedimentary arrangement at the site with a littoral deposit.

Aggregate extraction at the Pontax site has exposed bedrock. In places at Pontax, this bedrock forms roches moutonnées with striated and plucked surfaces and is

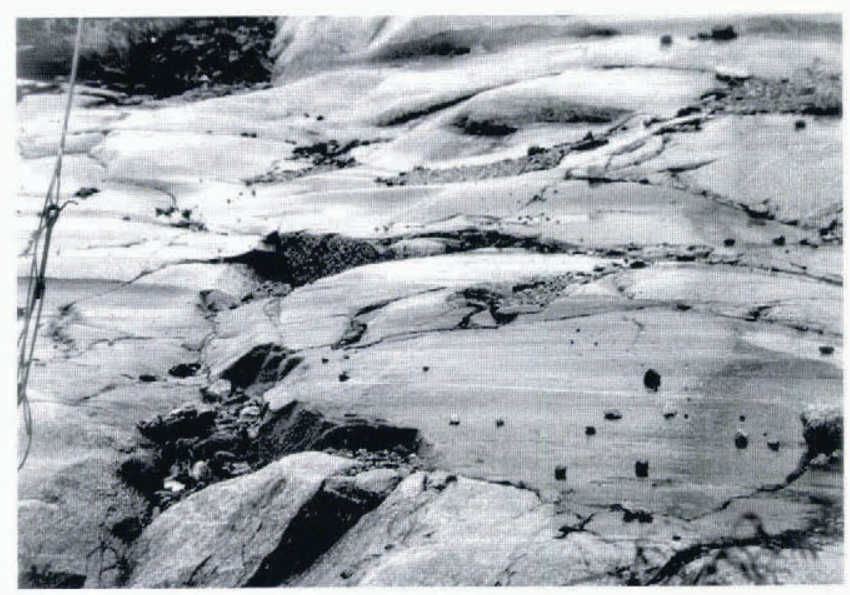

Fig. 9. Meltwater erosion marks in bedrock ( $S$-forms: musselbruche and open spindles) with superimposed striae, $\sim 43 \mathrm{~km}$ east-southeast of Matagami (32F/11, E 348300 , N 5494400). Meltwater flow towards left, $\sim 215^{\circ}$.

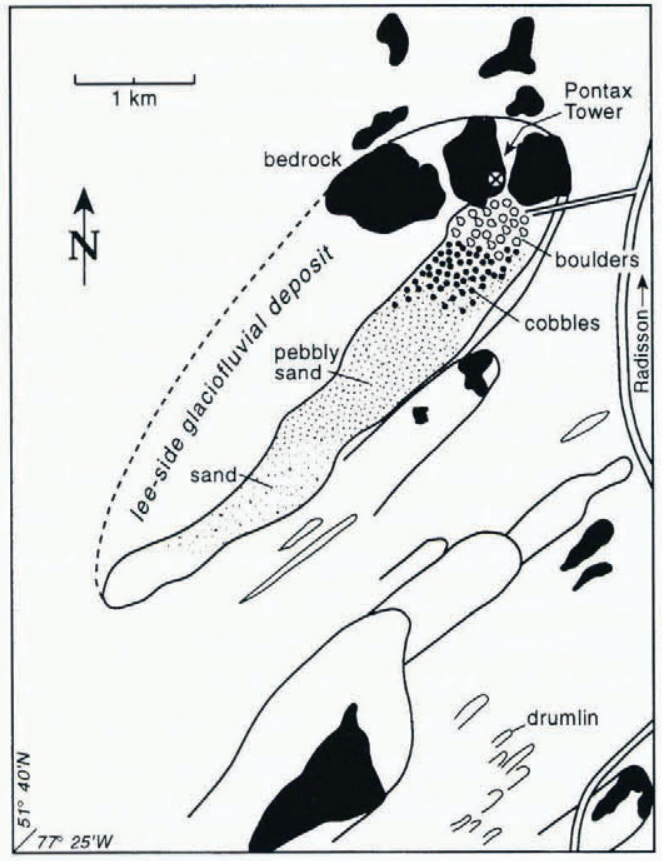

Fig. 10. Schematic plan view of Pontax site illustrating landform-sediment relationships.

overlain by diamicton (Fig. 11c). Elsewhere, bedrock with S-forms and striae, both indicating southwesterly flow, is overlain by sand and gravel (Fig. 11c). With the exception of light scratches on steep lee-side slopes of roches moutonnées and $\mathrm{S}$-forms, multiple striae directions were not observed at this site.

We interpret these observations at the Pontax site as follows. An initial episode of glacial plucking and abrasion produced roches moutonnées. Till was then deposited on the abraded and plucked bedrock. Later, meltwater flowing towards the southwest eroded S-forms in bedrock and probably also stripped till from much of the area. Regional, southwest-oriented streamlined forms and S-forms were probably also formed by this meltwater event. Ice again came into contact with the bedrock, and striations were superimposed on the Sforms at the Pontax site. This abrading event may have been short-lived. Meltwater subsequently deposited boulders grading downflow to sand in a flow expansion to the lee of the Pontax bedrock high. This meltwater event was powerful enough to carry metre-sized boulders directly over the Pontax bedrock high to their lee-side depositional site. Such transport would only have been possible if the ice sheet was separated from its bed both upstream and downstream from the bedrock high. Consequently, this high must have been immersed in a broad flow. In this interpretation, flow expansion, where the gap width between the glacier and the bed increased to the lee of the obstacle, caused deposition of the lee-side ridge.

The constructed sequence of events at Pontax fits neatly with the conclusions drawn from a more general regional view. It points to the overwhelming importance of meltwater in the late stages of the event sequence at Pontax and to the explanatory power of the meltwater outburst-flood hypothesis when applied at the local scale. 


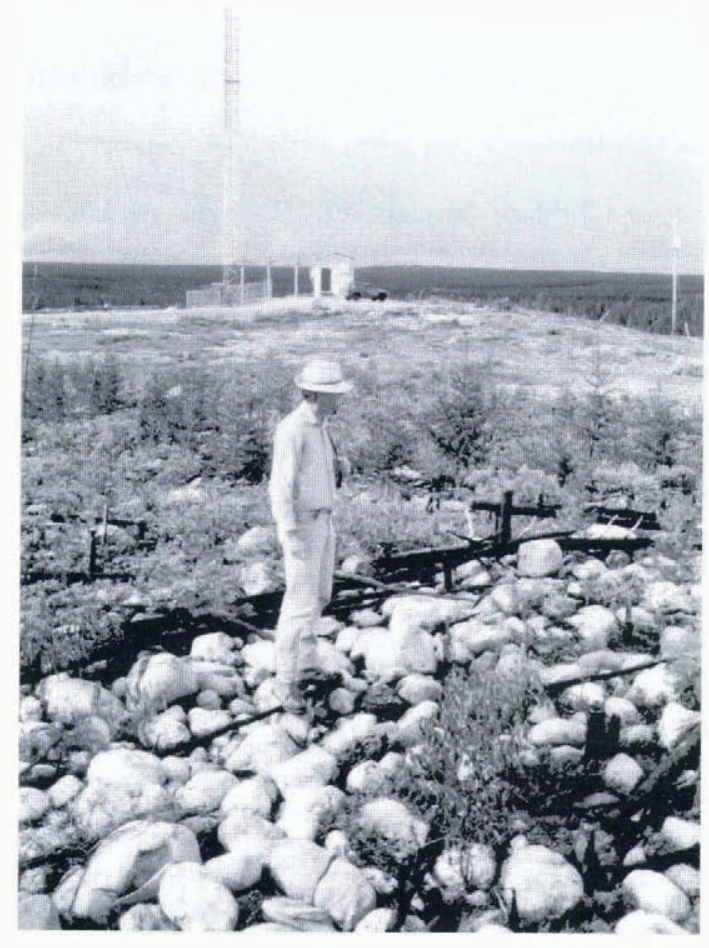

a

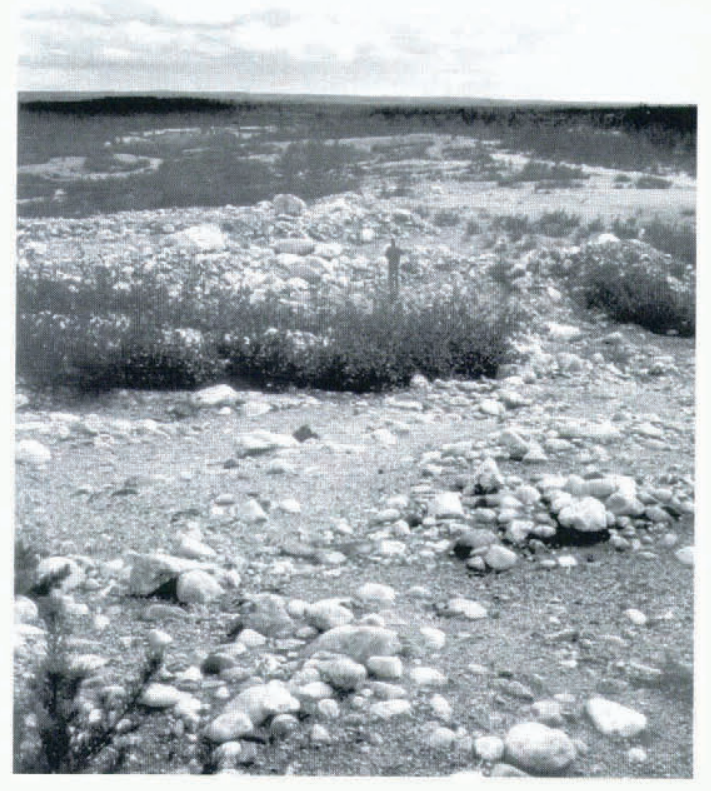

b
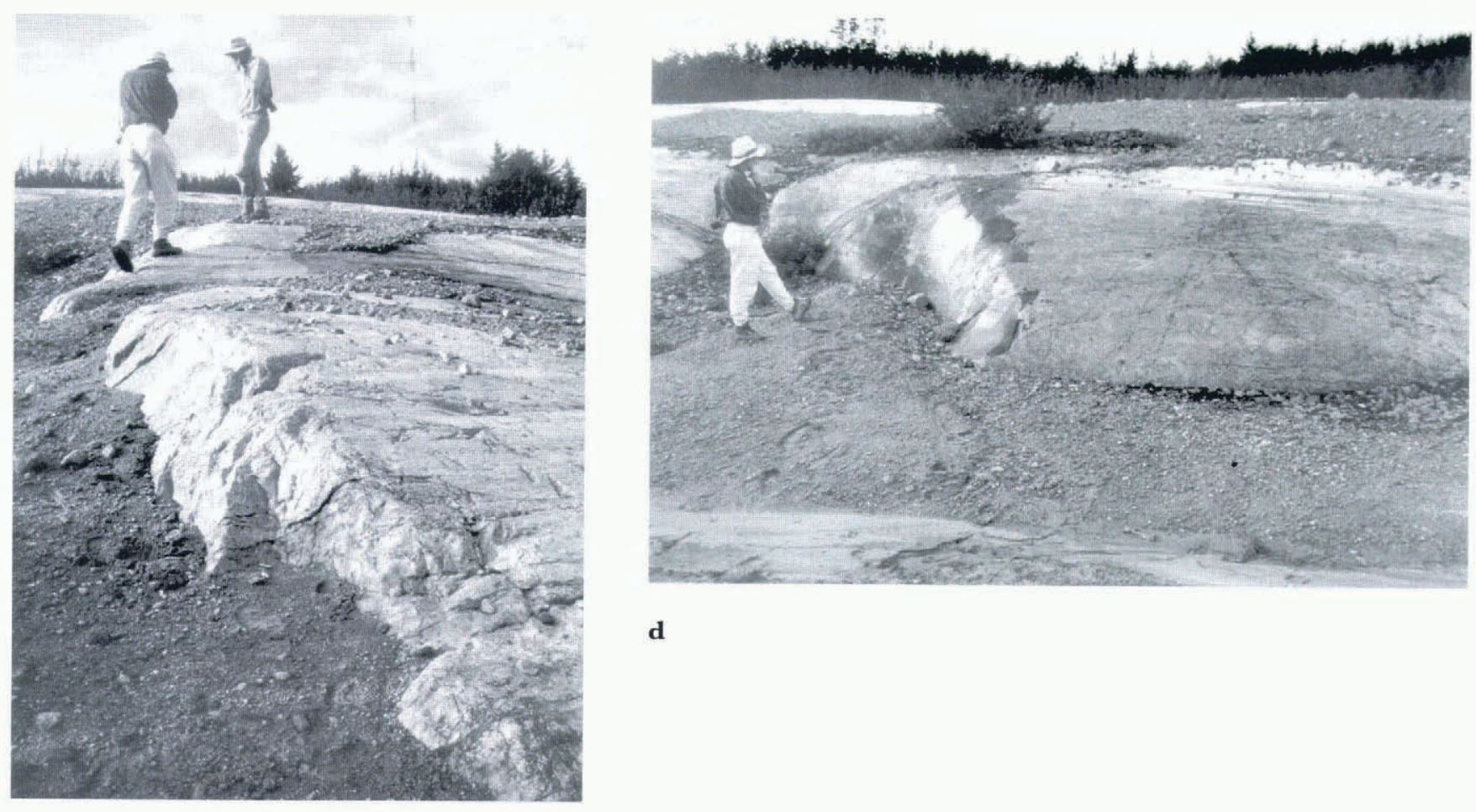

d

c

Fig. 11. Observations from the Pontax streamlined form. Sloss-side bedrock oulcrop with lee-side proximal glaciofluvial cobbles and boulders (a) passes distally into pebbles and sand (b). On the southeast flank of the Pontax site, both sandy diamicton preserved in the lee of a roche moutonée (c), and glaciofluvial sand preserved in the lee of S-forms (d) are observed.

\section{IMPLICATIONS}

Linking the Harricana moraine and regional outburstflood events indicates the potential importance of catastrophic events during deglaciation of the Laurentide ice sheet. We suggest that a set of streamlined forms in the study area resulted from an extreme-magnitude event when the ice sheet was close to its maximum extent.
The location of the Harricana moraine was inherited from this event. Other, high-magnitude outburst floods are thought to have been released about this time Shaw, 1994b). The effects of these floods must have extended beyond those considered here on the subglacial landscape. Storage and release of enormous volumes of meltwater must have affected ice-sheet form and flow. Erosion and deposition by these floods must have had dramatic 
consequences for extraglacial river valleys and ocean floors. Ocean chemistry, turbidity and temperature would have been directly affected. Indirect effects on ocean circulation and heat exchange with the atmosphere would ultimately have affected climate.

\section{ADDENDUM}

We have written a story about the Harricana moraine as an esker, based on our observations and those of others. In our account of events, these observations fit together without contradiction. We believe that our observations are at odds with the conventional explanation that the esker was formed segment by segment over time. A reviewer asks what it would take for us to accept the conventional view. There are two ways to answer this question. First, if the conventional story can incorporate the new sedimentological observations, we would accept that both stories are valid (note that neither need be true), and we would search for further information to help us choose between them. Secondly, and more decisively, if the proponents of the time-transgressive story demonstrate that the esker is made up of segments with sedimentary trends terminating at ice-marginal fans and that recessional moraines are associated with these fans we would accept their view. As things stand, we are left wondering about the regional trends in esker morphology and sedimentology and the apparent absence of punctuating marginal fans and recessional moraines along the length of the esker. We do not see how these observations can be woven into the conventional story.

\section{ACKNOWLEDGEMENTS}

We wish to thank J.J. Veillette for initially provoking our interest in the area and providing us with valuable information and guidance. M. Fisher and D. Viner drafted the figures. This manuscript was reviewed by J. Andrews and A.S. Dyke.

\section{REFERENCES}

Brennand, T.A. 1994. Macroforms, large bedforms and rhythmic sedimentary sequences in subglacial eskers, south-central Ontario: implications for esker genesis and meltwater regime. Sediment. Geol., 91 (-4), $9-55$.

Brennand, T.A. and J. Shaw. In press. The Harricana glaciofluvial complex, Abitibi region, Quebec: its genesis and implications for meltwater regime and ice-sheet dynamics. Sediment. Geol.

Dredge, L. A. and W. R. Cowan. 1989. Quaternary geology of the southwestern Canadian Shield. In Fulton, R.J., ed. Quaternary geology of the Canadian Shield in Quaternary geology of Canada and Greenland. Ottawa, Ont., Geological Survey of Canada, 214-249. Geology of Canada 1, K-1 Geology of North America.)

Dyke, A.S. and V.K. Prest. 1987. Late Wisconsinan and Holocene history of the Laurentide ice sheet. Géogr. Plys. Quat., 41 (2), 237-263.

Hardy, L. 1976. Contribution à l'étude géomorphologique de la portion Québécoise des Basses Terres de la Baie de James. (Thèse de doctorat, Université McGill.)

McClenaghan, M. B. 1990. Summary of results from the Black RiverMatheson (BRiM) reconnaissance surface till sampling program. Ont. Geol. Surv. Open File Rep. 5749.

McDonald, B. C. and W. W. Shilts. 1975. Interpretation of faults in glaciofluvial sediments. In Jopling, A. V. and B. C. McDonald, eds. Glaciofluvial and glaciolacustrine sedimentation. Tulsa, OK, Society of Economic Paleontologists and Mineralogists, 123-131. (SEPM Special Publication 23.)

Ministère de l'Énergic et des Ressources, Québec (MERQ) and Ontario Geological Survey (OGS). 1983. Lithostratigraphic map of the Abitibi Subprovince, 1:500000. Québec, Ministère de l'Énergie et des Ressources and Ontario Geological Survey, DV 83-16 and 2484.

Powers, M. C. 1953. A new roundness scale for sedimentary particles. J. Sediment. Petrol., 23 2), $117-119$.

Prest, V.K., D. R. Grant and V.N. Rampton. 1968. Glacial map of Canada. 1:5,000000. Ottawa, Ont., Geological Survey of Canada. (GSC Map 1253A.)

Punkari, M. 1980. The ice lobes of the Scandinavian ice sheet during the deglaciation in Finland. Boreas, 9 4), 307-310.

Punkari, M. 1985. Glacial geomorphology and dynamics in Soviet Karelia interpreted by means of satellite imagery. Fennia, 163 (1), $113-153$.

Shaw, J. 1994a. Hairpin erosional marks, horseshoe vortices and subglacial erosion. Sediment. Geol., $91(1-4), 269283$.

Shaw, J. 1994b. A qualitative view of sub-ice-sheet landscape evolution. Prog. Phys. Geogr., 18 2), 159-184.

Sneed, E. D. and R. L. Folk. 1958. Pebbles in the lower Colorado River, Texas: a study in particle morphogenesis. J. Geol., 66 2), 114-150.

Veillette, J.J. 1986. Former southwesterly ice flows in the AbitibiTemiskaming region: implications for the configuration of the Late Wisconsinan ice sheet. Can. J. Earth Sci, 23 (11), 1724-1741.

Veillette, J.J. 1990. Le dernier glaciaire au T'émagamingue, Québec et Ontario. (Ph.D. thesis, Université Libre de Bruxelles.) 